\title{
Value Co-Creation in Engineering Service Innovation: Resources and Capabilities Perspectives
}

\author{
Gintarẻ Gegužytè1, Liudmila Bagdonienė
}

Submitted: 19.08.2020. Accepted: 16.08.2021

\section{Abstract}

Purpose: This research focuses on firm resources and capabilities used for value co-creation in service innovation. Specifically, I investigated how service innovation is created in an international engineering company. The aim of this article is to reveal what resources and capabilities are employed by a service provider for value co-creation in the innovation project of engineering service and how they vary in particular stages of this project.

Methodology: The research is based on qualitative methodology by a multi-case study strategy. Focus group discussion with senior managers and semi-structured interviews with project managers of the studied international engineering company were used as concrete data gathering methods.

Findings: The research revealed eight value co-creation activities accomplished by the engineering company and client during the engineering service innovation project. The activities are as follows: co-identification of the client's problem, co-evaluation of ideas, co-defining of client's requirements, co-analysis of environment, co-design, co-testing, and co-adoption, co-production, and co-activities after the launch. These activities are diffused in different project stages and demand a range of resources: expert knowledge, diagnostic, communication skills, trust, experience, technological equipment, human resources. Moreover, they require diverse capabilities: relational, innovative, analytical, negotiation, knowledge absorptive, planning, organizational flexibility, and cross-cultural. The intensity and variety of using the mentioned resources and capabilities differ relying on the value co-creation activity. We hope these findings will represent a step toward a more coherent resource-based view (RBV) and service innovation theories.

Implications: The study involved only one Lithuanian engineering company, so the research context may influence the findings. Another limitation is related to the small number of cases and research participants.

Originality: Unlike previous studies that revealed the importance of single resources and capabilities for service innovation, this study determined the range of resources and capabilities employed in different activities of engineering service innovation project stages, especially in the value co-creation activities performed by the engineering company and clients. Moreover, research also identified how resources and capabilities vary at different stages of these projects.

Keywords: service innovation, resources, capabilities, value co-creation, engineering company, Lithuania.

\section{JEL: L840, 0310}

\footnotetext{
1 Corresponding author: Kaunas University of Technology School of Economics and Business Gedimino str. 50 Kaunas 44029, Lithuania; gintare.geguzyte@ktu.edu; https://orcid.org/0000-0003-4747-2067.

2 Kaunas University of Technology School of Economics and Business Gedimino str. 50 Kaunas 44029, Lithuania; liudmila.bagdoniene@ktu.It.
} 


\section{Introduction}

In the modern economy, service firms must continuously reinvent themselves to adapt to a complex and dynamic business environment and retain competitiveness. In this respect, innovation is a major source of service firms' progress and success. Service innovation is a broad and complex concept (Giannopoulou et al., 2011). Service innovation comprises new services, new service provision processes, new organizational structures or marketing strategies (Sørensen and Lapenta, 2017), technology innovation, business model innovation, social-organizational innovation, and demand innovation with the objective of improving existing services, creating new value propositions, or creating new service system (Ostrom et al., 2010; Snyder et al., 2016).

The success of service innovation is influenced by the effective development of the process, that is why service organizations make efforts to formalize or structure service innovation processes. The models deconstruct the service innovation process into diverse stages from idea to launch and reflect practices that deal with the sequencing of service innovation development activities. The resources in these models are usually seen as auxiliary or secondary compared to the stages and activities of the sequence of service innovation process (Fitzsimmons and Fitzsimmons, 2006). Froehle and Roth (2007) emphasize the need for examining the development and the deployment of resources needed for a company's service innovation. According to them, an organization that develops competencies in both process-oriented and resource-oriented practices enriches service innovation capabilities that differentiate it from its rivals and conduce to continued innovation and growth.

Service innovation is the primary source of value creation (Chen et al., 2016), so more and more firms expand their innovation activities through co-creation (Mahr et al., 2014). Value co-creation is the joint, collaborative, concurrent, peer-like process of producing new value (Galvagno and Dalli, 2014), which helps to extract distinctive ideas from clients (Janteng and Tan, 2017) and anticipates firms' innovation capabilities (Galvagno and Dalli, 2014). Drawing on service-dominant logic (SDL), Paredes et al. (2014) define value co-creation as a process by which firms and customers integrate their tangible and intangible resources to generate value. Allen et al. (2009) state that a firm is an active agent who initiates value co-creation. Kim et al. (2015) and Sirmon et al. (2007) indicate that merely possessing resources does not guarantee the creation of value. Organizations must bundle resources to build capabilities and leverage those capabilities in creating value with customers. 
Nevertheless, studies focused on value co-creation in service innovation are scarce (Frow et al., 2015; Islam et al., 2015). This is especially true concerning value co-creation in the industrial service environment. One reason for this is that value co-creation has been extensively researched in business-to-customer and much less in the business-to-business context, which is the case of industrial services such as engineering, predictive maintenance, advanced process diagnostics and fleet management (Bonamigo et al., 2020). Furthermore, very little is known about resources and capabilities that companies seek for the purpose of service innovation (Lindgreen et al., 2012; Rusanen et al., 2014), and the questions how value co-creation leads to successful innovation is still in its infancy (Gemser and Perks, 2015; Kim et al., 2015). In the particular context chosen for this article - engineering projects - the above-described knowledge gap is especially prevalent. Based on the above considerations, this article seeks to reveal what resources and capabilities are employed by a service provider for value co-creation in the innovation project of engineering service and how they vary in particular stages of this project.

The remainder of this paper is structured as follows. First, we will provide a brief theoretical background on value co-creation with business clients, resources, and capabilities used for service innovation creation, along with engineering service's project as service innovation. Second, we will introduce the research design and study context. Third, we will present and discuss the key findings of the study. The article will end with concluding remarks, practical implications, and further research.

\section{Theoretical Background}

\section{Value Co-Creation with Business Client}

Co-creation as a new paradigm in management allows companies and clients to create new common value. From this perspective, the company and client are no longer on opposite sides but collaborate for discovering new business opportunities. Co-creation is defined as joint, collaborative, concurrent, peer-like process of producing new value (Galvagno and Dalli, 2014) and is viewed as a particular form of open innovation (Frow et al., 2015). From an organization's perspective, co-creation can enhance its innovation processes and unlock new sources of competitive advantage (Frow et al., 2015; Kaszowska-Mojsa, 2020). As DeFillippi and Roser (2014) state, many companies increasingly often employ value co-creation to engage clients in their search for innovation. This tendency leads to changes in the traditional understanding of innovation, in which the supplier is the innovator and the client is the recipient of innovation, thus replacing it by the understanding of innovation based on service-dominant logic, in 
which the client becomes the real co-innovator who exchanges and integrates resources to co-create value (Gummesson et al., 2010). Every actor contributes to value co-creation by integrating available resources through different forms of co-creation: co-conception of ideas, co-design, co-production, co-promotion, co-pricing, co-distribution, co-maintenance, co-disposal (Frow et al., 2015).

Acting as the co-creator of value provides diverse benefits: from increased speed to market, lower risk of market failure, and enhanced innovation capabilities of the company through reduced costs of existing innovation approach to a deeper focus on value creation rather than for technological solutions (DeFillippi, Roser, 2014). On the other hand, co-creation implies some sacrifices, e.g. sharing information with clients. Thus, in order to achieve successful co-creation, companies should identify and analyze carefully potential benefits and sacrifices. In the field of high technology and knowledge-intensive business services - which is the case of engineering services explored in this study - co-creation is conceptualized as a joint problem-solving process between the client and provider. This process includes diagnosing needs, designing solutions, organizing processes, managing conflicts, and implementing solutions (Aarikka-Stenroos, Jaakkola, 2012). When business clients engage in joint problem-solving activities with the provider, they often have no precise understanding of their own needs and lack the necessary skills to articulate desired solutions elements. In this context, the provider gains control over the management, organization, and overview of a successful value co-creation process (Grafmüller, 2020). The implementation of innovative projects based on value co-creation requires changes throughout organizations, meaning the adoption of a new mindset. Executives must assume critical roles in the initiation and evolution of a co-creative organization (Jouny-Rivier et al., 2017).

\section{Resources and Capabilities}

Innovation provides organizations the opportunities to grow faster, better, and smarter than their rivals (Sáenz et al., 2009; Benazzouz, 2019; Kaszowska-Mojsa, 2020). In today's competitive landscape, service innovation is seen as the main engine of economic growth and differentiation across firms and markets (Snyder et al., 2016; Helkkula et al., 2018). Service innovation creates value for customers, employees, business owners, alliance partners, and communities; it comes in many forms such as new or improved service offerings, service processes, and service business models (Ostrom et al., 2010); it ranges from the discovery of complex new technologies through simple incremental additions to existing knowledge (Paradkar et al., 2015). 
In order to create and develop service innovation, various resources are needed. We should remember that resources have many definitions. Barney (2002) defines resources as all the assets, capabilities, competencies, organizational processes, firm attributes, information, and knowledge that are controlled by a firm and that enable the firm to conceive of and implement strategies for the improvement of its efficiency and effectiveness. Edvardsson and Tronvoll (2013) state that a resource is anything that has the potential to be operated or used by actors to enable and foster their resource integration and value co-creation efforts.

Historically, an established typology has delineated between material, "raw" resources and immaterial, dynamic resources (Campbell et al., 2013). The simplest approach distinguishes between tangible resources (e.g. finances, materials) and intangible resources (e.g. knowledge, skills, and capabilities; Grant, 1991). Barney (1991) foregrounds firms' physical capital resources, human capital resources, and organizational capital resources. Hunt (2000) maintains that resources can be financial, physical, legal, human, organizational, informational, and relational. Das and Teng (2000) divide all resources into property-based (PBR) and knowledge-based (KBR). The former consist of discrete rights to exploit assets protected from appropriation and imitation by the law, while KBR consist of technical skills and social knowledge that take time to be acquired. Tangible or "raw" resources may be easily purchased or imitated by competitors in markets. Conversely, the value of intangible (immaterial) resources depends on company competency. Consequently, intangible resources have more strategic value due to their uniqueness and difficulty in imitation or substitution (Paradkar et al., 2015).

Service-dominant logic separates operand and operant resources. Operand resources are treated as passive and operant resources as active resources (Vargo and Lush, 2008). Operand resources are inert, so they require action to create benefit. Operant resources are a combination of skills, knowledge, and competencies which - when they act on operand resources - create value for the firm (Agrawal and Rahman, 2015). Service innovation relies more on operant than operand resources (Hsieh and Hsieh, 2015). Moreover, operant resources determine the degree of service innovativeness (Michel et al., 2008).

However, the possession and control of various resources is not sufficient for long-term survival (Strønen et al., 2017). In order to create a competitive advantage, an organization should be able to combine, develop and exploit resources. This indicates that resource combination is an effective mechanism to transform the resources into capabilities (Lichtenstein and Brush, 2001). Hence, capabilities are mastered through the utilization of resources (Carroll and Helfert, 2015). Grant (1991) states that capabilities 
may take the form of routines and interactions by which the firm's other resources are coordinated. Teece (2014) affirms that capabilities are a firm's capacity to utilize resources to perform an activity that flows from the bundling or orchestration of resources. According to O'Connor (2008), capabilities are the business processes needed to configure assets in advantageous ways. Organizations that are able to build capabilities by combining resources in unique ways can access intricate bundles of resources with which to successfully compete with rivals (Hervas-Oliver and Sempere-Ripoll, 2015; Sułkowski and Patora-Wysocka, 2020). The most established classification of capabilities distinguishes them as either static or dynamic. Firms' static capabilities are those essential routines and practices that often require having a high level of technical need supporting firm activities (Urueña et al., 2015). Whereas dynamic capabilities focus on a firm's ability to strategically manage and deploy resources through repeatable patterns in order to achieve business objectives (Giannopoulou et al., 2011).

A similar approach is expressed by Koryak et al. (2015). They highlight the importance of growth capabilities that enable a firm to compete in the market on a day-to-day basis (growth capabilities agree with static capabilities) and dynamic capabilities, which extend, modify, or create new growth capabilities. Hence, static capabilities mean stationary or fixed capabilities while dynamic capabilities may be defined as energetic, capable of action or change, and forceful. Usually, organizations possess different capabilities that are described by four dimensions: (1) employee knowledge and skills, (2) technical systems, (3) managerial systems that conduct knowledge creation and control processes, and (4) the values and norms related to these processes (Löfsten, 2016). According to Christensen (2013), organizational capabilities comprise human, technological factors, material resources, processes, and criteria for decision-making. These arise from the skills and abilities that enable the application of resources and reflect an ability to continuously transform knowledge and ideas into new products, services, processes (Hogan et al., 2011).

Bello et al. (2016) focus particularly on service innovation capabilities, which play an important role in the successful development of different service innovations. These multidimensional capabilities are embedded in organization routines or processes and have the potential to recurrently distribute and reconfigure resources in the persistent creation of new or improved services. Service innovation capabilities allow organizations to retain flexibility and adapt to their environment through the repeated and continuous creation of innovations (Giannopoulou et al., 2011). Although organizational capabilities play a significant role in creating innovation through actors' value co-creation (Urueña et al., 2015), nonetheless, there is an absence of agreement as to which capabilities are critical to the development of innovative service outputs 
(Gryszkiewicz et al., 2013). To summarize, successful service innovation by value co-creation requires the integration of various resources and a company's ability to use these resources purposefully and creatively.

\section{Engineering Project as Service Innovation}

Engineering services are typically knowledge-intensive, project-based, and people-centric business services. They usually have a long life cycle, representing a distinctive business model (Løwendahl, 2005; Malhotra and Morris, 2009; Von Nordenflycht, 2010). They play a critical role in the supply of innovative solutions related to e.g. infrastructure, buildings, electricity, urban transport, water systems. As knowledge-intensive business services, engineering services employ skills and talents of different professions and organizations (Nicholas and Steyn, 2017). These knowledge and expertise are needed to reflect the best practices for achieving low cost, versatility, and reliability (Miller, 2001).

Engineering services are project-based and are reasonably treated as creators of innovations (products, service, processes) for almost every organization (business, government; Siegel, 2019). Engineering innovation outlines what it takes to transition a new concept into a successful product, service, or process (Legum et al., 2019). As an innovation, an engineering service project means a process from idea to its realization (Stošić and Milutinović, 2017), which is divided into four phases, each with numerous activities (Duffy, 2008). Every engineering service project is unique: it is developing based on market demand and diverse goals, intricacy, and time. Baark (2001) notices that every engineering project can encapsulate many different innovative elements, e.g. it can adapt existing technology to local conditions or uniquely assemble technical constituents. Moreover, the engineering innovation process can occur as a subtle change, e.g. innovation can be inspired by observing how the client has modified the design and process for better use. Furthermore, often in an engineering project, innovation means the complex business solution that combines the product and process. That makes sense in services where the border between a service and its delivery process is unclear (Santos-Vijande et al., 2012), which is exactly what engineering services are. In summary, engineering service innovation is complex and multidimensional.

As with many innovations, engineering service projects are risky and show high failure probability (Miller and Lessard, 2001; Nicholas and Steyn, 2017). Projects may face market-related (demand, financial, and supply), completion (technical, construction, and operational), and institutional risks (regulatory, social acceptability; Miller and Lessard, 2001a). It is a laborious task to avoid failures, cope with project problems, 
and reach project success (Nicholas and Steyn, 2017). As Stošić and Milutinović (2017) note, success depends on the project team and especially the project manager. $\mathrm{S} /$ he is responsible for project planning, communication, control, and achieving a project goal. Moreover, a project manager should nurture trust among team members, along with integrating their efforts, skills, knowledge, and experience. Usually, contemporary engineering projects are international, so they require cross-cultural competence that positively influences a team's work and can be seen as an assumption of project success (Henrie, 2014). Project management leaders feel incessant pressure to innovate and prepare their products, services, and teams more creatively than ever before. This suggests an imperative to manage a complex set of resources, capabilities, systems, processes, procedures, and tools that enable us to achieve the engineering service innovation project goals of all interested parties.

\section{Research Design and Study Context}

The study was based on qualitative methodology, selected for three reasons. First, qualitative methodology allows us to understand a complex reality and the meaning of actions in a given context, and it produces in-depth information that help to understand the various dimensions of the problem under analysis (Queirós et al., 2017). Furthermore, qualitative methodology allows to better understand the perspectives of study participants. (Green and Thorogood, 2013). Third, qualitative research is appropriate when little is known about a topic and when researchers want to learn more about the matter (Antwi and Hamza, 2015). Fourth, qualitative methodology often relies on personal contact over time between the researchers and the group under analysis, which is exactly the case of our study. Building a partnership with study participants leads to a deeper insight into the context under scrutiny and adds richness to the data (Ulin et al., 2005).

Two motives have stimulated us to select engineering services for analysis. First, it was the innovative nature of engineering services, which often refer to the development of completely new products or processes. Seeking to help companies in solving the complex problems arising from the modern business environment, engineering companies design and develop ever-new machinery, materials, instruments, structures, processes, and systems. Engineering services may involve consulting, feasibility studies preparation, planning, design, technical services, inspection, engineering projects evaluation, and other related services. Thus, the industry of engineering services is technology-driven and highly innovative (Kantola and Karwowski, 2016). The second reason to study engineering services is the fact that we still know very little about 
how engineering services companies deploy their resources at different stages of service innovation projects and what capabilities they require for creating innovative solutions for business problems.

The study was performed in a Lithuanian engineering services company that operates in various European, Asian, and African countries, including Russia, Belarus, Uzbekistan, Kazakhstan, and Azerbaijan. Recently the company started its business in the Iranian market. The studied company belongs to a group of small and medium-sized enterprises. In 2020, the company had 30 employees, and its total revenues reached EUR 6.54 million. The company has been implementing innovative solutions for water treatment, condensates, and wastewater for over 25 years. The company offers the following services: equipment design, manufacturing, installation, start-up and adjustment, technical support, and maintenance. In the water treatment process, the company uses both traditional and unique water treatment technologies, developed by the company engineers. The company serves clients from different industries: electric power, oil refining, chemical, food, paper-making, pharmaceutical, textile, electronics, glass-making, agriculture industries. Moreover, the company delivers services for municipal drinking water supply systems. The diversity of served industries, expertise, and rich experience in implementing engineering projects were the main criteria why we selected this company for the study. My personal contacts with the company community and the company's interest in this study were additional reasons.

So as to reach the aim of this study, engineering service innovation projects were selected from a pool of realizable projects based on four criteria: (1) the technology used, (2) the industry of project implementation, (3) project duration, and (4) project size. Multiple cases reflect a different reality (Stake, 2005) and help researchers to better understand differences and similarities between cases (Baxter and Jack, 2008). The information about selected projects is provided in Table 1 (in order to ensure confidentiality, projects are listed anonymously).

As Table 1 above shows, we employed two methods for gathering primary data were employed: focus group and semi-structured interview. Focus group and semi-structured interview methods are the most widely used in qualitative research methodology (Antwi and Hamza, 2015). Using few methods helps researchers better understand studied phenomena and strengthens study reliability and validity (Yin, 2014).

Senior managers who typically lead the business management unit were invited to participate in the focus group discussion (Table 2). 
Table 1. List of studied engineering service innovation projects

\begin{tabular}{|l|l|l|l|l|c|}
\hline Project & \multicolumn{1}{|l|}{ Technology } & Industry & $\begin{array}{l}\text { Project } \\
\text { country }\end{array}$ & $\begin{array}{r}\text { Project } \\
\text { duration }\end{array}$ & $\begin{array}{c}\text { Project value } \\
\text { (million euros) }\end{array}$ \\
\hline Project 1 & Reverse osmosis & 0il refining & Bulgaria & 12 months & 2.5 \\
\hline Project 2 & Ultrafiltration & Energy & Belarus & 18 months & 4.4 \\
\hline Project 3 & Mechanic filtration & Oil refining & Iran & 8 months & 3.3 \\
\hline Project 4 & Ultrafiltration & Metal & Lithuania & 7 months & 1.4 \\
\hline Project 5 & Reverse osmosis & Water supply & Iran & 18 months & 1.1 \\
\hline
\end{tabular}

Source: own elaboration.

Table 2. Profile of focus group discussion participants

\begin{tabular}{|l|l|c|}
\hline Participants & Position in company & Work experience (in years) \\
\hline Participant 1 & CE0 (owner) & 12 \\
\hline Participant 2 & Technical director & 7 \\
\hline Participant 3 & Director of commerce & 10 \\
\hline Participant 4 & Automatization manager & 5 \\
\hline Participant 5 & Production manager & 8 \\
\hline
\end{tabular}

Source: own elaboration.

As demonstrated, focus group discussion focused on two main questions: 1) what company's distinctive features are important to the success of engineering service innovation projects, 2) what resources and capabilities lead to company competitiveness. The focus group discussion happened in the company's lounge and took 75 minutes. The focus group discussion was organized in January 2020.

Project managers perform tasks according to the goals and scope of the project and are in charge of conducting, controlling, and coordinating overall project activities. This is the main reason why project managers were invited to participate in semi-structured face-to-face interviews (Table 3). Consequently, all invitees consented to the interviews.

The main topics included in the semi-structured interview questionnaire were: 1) stages of an engineering services innovation project, 2) value co-creation activities with 
clients during an engineering services innovation project, 3) resources and capabilities necessary in different phases of an engineering services innovation project. The semi-structured interviews were conducted in the informants' workplaces, and each of the meetings took 45-70 minutes. The participants were open and interested in the study. The semi-structured interviews were held in March 2020.

Table 3. Profile of semi-structured interview participants

\begin{tabular}{|l|l|l|c|}
\hline Participants & $\begin{array}{c}\text { Position in } \\
\text { company }\end{array}$ & Projects & $\begin{array}{c}\text { Work experience } \\
\text { (in years) }\end{array}$ \\
\hline Participant 1 & Project manager & $\begin{array}{l}\text { Project 2 } \\
\text { Project 4 }\end{array}$ & 7 \\
\hline Participant 2 & Project manager & Project 1 & 6 \\
\hline Participant 3 & Project manager & Project 5 & 10 \\
\hline Participant 4 & Project manager & Project 5 & 6 \\
\hline Participant 5 & Project manager & Project 3 & 5 \\
\hline
\end{tabular}

Source: own elaboration.

In both cases - focus group discussion and semi-structured interviews - supplementary questions were asked to follow up on interesting ideas and to direct the discussion toward expected themes.

The data obtained from the focus group participants and interviewees were transcripted and analyzed using qualitative content analysis (Roller and Lavrakas, 2015) in an inductive manner. Inductive content analysis is used when there are no previous studies dealing with the phenomenon (Hsieh and Shannon, 2005), meaning that it is driven by data (Anandarajan et al., 2018). The sequence of inductive content analysis is the following. First, transcripts of recorded focus group discussions and interviews were chosen as units of analysis. Second, records were transcribed and analyzed. Participants were asked to review the resulting write-ups as a precaution against misunderstanding and transcription errors (Gibbert et al., 2008). Third, the texts were divided into condensed meaning units like words, sentences, or paragraphs related to each other by content. Fourth, each condensated unit was abstracted and labeled with a code. Fifth, various codes were compared based on relationship aspects of underlying meanings, and the same meanings were grouped together, which formed first-order categories. The first-order categories were combined to create second-order categories, which were based on study participants' expressions and the qualitative content of 
their meaning. Finally, the first- and second-order categories were gathered into aggregated dimensions.

\section{Main Findings}

\section{Focus Group Discussion Findings}

The first topic of focus group discussion has uncovered five company's distinctive features that are important to the success of engineering service innovation projects. The first one is that the company has more than 25 years of experience in the water systems engineering business. Long-term experience leads to the company's exceptional expertise. This is the keystone to implement unique water systems projects, which offer innovative engineering solutions based on newly created or improved water technologies. The highest quality standards of all engineering innovation projects were named as a second trait.

The discipline of project implementation terms serves as a standard that distinguishes the company in the market. The duration of projects ranges from six months to several years, and it depends on the complexity of the order, the industry, the country in which the project is implemented, the timeframe for subcontracting, and other reasons. Despite tight deadlines, the company fulfills its commitments to complete projects on time. Exceptional quality including full service was listed as the third distinctive trait of the company.

The company offers a complete water treatment solution implementation from concept to realization. It means that the company provides consulting services on all water treatment matters, the design of water treatment systems, the automation of water treatment process, equipment manufacturing, the warranty and post-warranty service of equipment, the manufacturing of test equipment for technologic processes and testing, and short-term equipment lease. Full service enables the company to find appropriate solutions and conduct each water treatment system individually. In other words, the company is strongly oriented toward clients' needs. The company's solutions are used by more than 700 companies from different industries, such as electric power, food, papermaking, pharmaceutical, healthcare, electronics, agriculture, textile, oil refining, and metallurgic. Many of these firms are worldwide leaders in their own fields.

Attention to organizational learning is the fourth distinctive trait of the company. The company improves itself over time through gaining experience and using it to create knowledge. As the last distinctive feature, interviewees mentioned partnerships and 
networking. The company operates in different markets, many geografically remote, so trusted partners in each market facilitate and accelerate project implementation. Partnership is particularly important to acquiring and disseminating knowledge. In summary, the company's features create preconditions for the company to be the leader in water treatment technologies and be the first choice of clients, partners, and suppliers. Table 4 provides the detailed results of the interviews.

\section{Table 4. Distinctive features of the company}

\section{First-order category and representative quotes}

Each water treatment project is unique. The company always provides solutions suitable for clients' individual water treatment needs.

Our products and technologies are continually improved.

Our company creates innovative solutions that ensure waste-free water treatment, save nature and energy resources.

Our company attempts to be approachable to clients in order to better understand their needs.

Knowledge of the local market and understanding of clients' specificity enable us to offer them optimal solutions.

Our company offers a full-service package for clients.

Quality of our company's products is approved by ISO quality certificates.

Our company uses only high-quality equipment of well-known manufacturers. It allows us to ensure reliability, durability, and required qualitative parameters.

Reliable functioning of our equipment and stable parameters of treated water ensures our clients' smooth operation of production facilities.

Our employees renew their knowledge in a systematic way and improve their qualifications.

Our team is deeply experienced in water treatment area. This enables us to find the best solutions for each particular situation.

We are working with partners in each market.

Our wide office and partnership network ensures timely and quality service.

Our goal is a long-term cooperation. We create value by disseminating our knowledge to our partners.

\section{Second-order Aggregate category dimension}

Leader in water treatment technologies
Response

to clients need

Organizational learning

Partnership and networking
Priority

choice for clients
Priority choice for partners and suppliers

Source: own elaboration. 
Company resources and capabilities covered the second issue of the focus group discussion. Table 5 provides a comprehensive list of the company's resources and capabilities disclosed during qualitative content analysis.

Table 5. Company resources and capabilities

\section{First-order category and representative quotes}

The company often operates without an advance payment or with very small advance payment throughout the entire project.

The company requires tools, special loom, lifts, autoloaders, etc.

We operate in different industries and face with various clients' problems and requirements, so we need to know how to create engineering solutions.

We have been operating in this market for many years, so we have a set of necessary tools, and our systems have been tested in many ways.

Many advanced/cutting-edge technologies, along with traditional technologies built in the company are used to project implementation.

Clients trust us. They know that despite complex issues, our company can implement the project from beginning to end. We are responsible and reliable suppliers.

Our company is very well known in local and international water treatment technologies markets.

The project must have the required number of staff. The quality of work and compliance with deadlines depend on it.

The company often operates under uncertain circumstances. It may be the changes in clients' needs, legislation, entry to a new market, employment issues, etc. Nevertheless, the company can solve these problems quickly and efficiently.

It is not sufficient to correctly forecast the costs and prices, timeframe, sequence of project, etc. We need to predict the things that the company will be able to give up later because the company will have to accept the client's position.

Employees learn from everything that is possible, for instance, from their experience and then apply their learning to perform successfully in situations of uncertainty.

Bargaining is very important, frequently the most important skill in the market.

Various disturbances are common in implementing innovation projects, so our engineers and other employees need to find ways to eliminate or prevent these incidents. It means they need to renew their knowledge and skills quickly by using external sources. The company has a system for doing this.

\section{Second-order Aggregate category dimension}

Financial

resources

Technological equipment

Expert

knowledge

Experience

Technology

Resources

Trust

Reputation

Human

resources

Organizational flexibility

Planning capabilities

Learning agility

Negotiation

Capabilities

Knowledge absorption 
A client should be able to understand the solutions that our company is going to implement. As collaborators, we need to understand each other and communicate during project implementation and later. Relationship building and the smoothness of communication are very important and very difficult.

Our company constantly seeks new ideas, implements them, and creates new solutions for our clients. We are often the first to create/develop and launch a particular water treatment system. This is our competitive advantage.

Management is a capability to lead and control the entire process, i.e. orders, deliveries, the manufacturing it-self.

Relational

capabilities

Innovative

capabilities

Managerial capabilities

Source: own elaboration.

Finances, technology, and technological equipment were named the main prerequisites to engineering service innovation projects. However, participants were much more likely to talk about competent staff, their expertise, and the experience gained from various projects. In addition, the discussion revealed the big value of client trust in the company and its reputation. According to the participants, it is difficult to say that one resource is more important than another. The lack of at least one element can seriously disrupt project planning and execution. Providing tangible necessary resources and nurturing intangible resources is the task of the company's senior managers. The capabilities revealed in the discussion could be conditionally divided into three groups. The first group gathers organizational flexibility and negotiation are related to the company's behavior in the market and its ability to win project orders. Learning agility, knowledge absorption, and innovative capabilities form the second group. These capabilities are crucial to project implementation. The third group includes planning and managerial capabilities. These capabilities are employed in everyday activities. The last type of capabilities mentioned by participants is relational capabilities. These are umbrella capabilities, which are required for all activities and are vital for both internal and external communication and collaboration.

As the participants noted, the competition in the water treatment solutions market is intense and the company constantly faces challenges. Therefore, leveraging resources and capabilities to the best extent is the key to maintaining and sustaining the company's competitive advantage.

\section{Findings of Semi-Structured Interviews}

The project managers lead different engineering services projects simultaneously. All the analyzed engineering service innovation projects are unique and differ in scope, 
complexity, duration, and involved partners, so a clear scheme of project activities sequence may facilitate their management. The participants of semi-structured interviews foregrounded fourteen activities implemented during project planning, build-up, implementation, and closeout stages (Table 6).

\section{Table 6. Stages and activities of engineering service innovation project}

\begin{tabular}{|l|l|}
\hline \multicolumn{1}{|c|}{ Project stage } & \multicolumn{1}{c}{ Project activities } \\
\hline Planning & Identifying the client problem \\
\hline Generating of ideas for problem solution \\
\hline Evaluating the ideas \\
\hline Preparing the proposal \\
\hline Analysis of the client business environment \\
\hline Defining the client's requirements \\
\hline Translating client requirements into water system design requirements \\
\hline Design of water system \\
\hline Ordering of components \\
\hline Production \\
\hline Implementation & Delivery of the equipment for client \\
\hline Testing and adaption \\
\hline Water system launch \\
\hline Aloseout
\end{tabular}

Source: own elaboration.

According to the interviewed project managers, all stages of the project and every activity of each stage are equally important but differ greatly in terms of managers' attention and time requirements. Nonetheless, international projects' activities require more flexibility and adaptability. Usually, more attention is needed in the planning stages so as to identify a client's business problem and prepare a proposal. Translating client requirements into water system design specifications and proper water system design are two of the most time-consuming activities in the build-up project stage. In the implementation stage, production activities, water system testing and adaptation, and water system launch were most often mentioned. Let us note that the interviewed project managers were unable to specify activities at the project closeout stage. 
Evidently, engineering service projects are performed following clients' demands. All project managers who participated in the study unanimously affirm that clients' contribution to value co-creation is a particular request and feature of engineering service innovation projects. The findings reveal that value co-creation activities happen at all stages of the engineering service innovation project, in which clients emerge as active co-creators of value (Table 7).

Table 7. Company and client value co-creation activities in engineering service innovation projects

\section{First order category and representative quotes}

Client does not always know what his company needs, thus, we discuss the issues, which often requires intellectual involvement and time.

We suggest a few ideas/solutions for client business problem. Client wants to know in detail the pros and cons of every idea. Client has his/her own criteria for evaluating our ideas.

Our company makes/prepares the technological scheme and sends it for client approval. We contact the main person of client company and adapt any necessary changes to client wishes/needs.

Equipment must be installed at the specific location, the water must be obtained from some place and supplied to another location, stored, and protected, so we need client's contribution. Client is interested in project implementation on time; he/she shows and explains to our employees everything we need.

Client checks our project, technological scheme, drawings, initial instructions, and specifications. Indeed, client operates as co-designer.

For clients to understand what is required, they need knowledge. By training a client, the company strengthens the bond with the client. If we help them, then they help us as well. Clients provide tips and help throughout the entire project.

Client must participate. We check how water system functions and adjust, alter something, etc. We show the clients what is happening, and they learn how to manage the system.

It is important to maintain communication with the client in a regular way because the functioning of the water system depends on that. Some trouble could be caused by the client's scarce knowledge in this area. We are ready to help. On the other hand, we obtain valuable information from the client when he addresses and asks how it is possible to improve the functioning of water equipment.

\section{Second order category}

Aggregate dimension

Co-identification of the client's problem

Co-evaluation of ideas

Co-defining of client's requirements

Co-analysis of environment Build-up project

\section{Co-design}

Co-production

Project implementation

Co-testing and co-adoption

Co-activities after the launch (e.g. mutual information Closeout exchange, co-learning)
Project planning

Source: own elaboration. 
Notably, not all engineering service innovation project activities comprise value co-creation with clients, e.g. proposal preparation in the project planning stage or client requirements translation into water system design specification in the build-up stage. The scope of co-created activities varies among project stages. The build-up project stage is characterized by more co-creation activities than other stages. As the participants mentioned, it is difficult to clearly separate the activities of one stage from other stages. It is more important to ensure that the expected outcome of a specific activity will be reached. Co-creation activities differ also by the manner of their execution: some are conducted in situ - i.e. at the studied company (e.g. co-production) - while other at the client company (e.g. co-testing and co-adaption of the water system).

An engineering project is a sophisticated process that consumes different resources and requires various capabilities. Table 8 demonstrates what resources and capabilities were used in engineering service innovation projects and how they varied in different project stages and concrete activities of value co-creation with clients.

Table 8. Resources and capabilities employed to value co-creation in engineering service innovation projects

\begin{tabular}{|c|c|c|c|c|}
\hline $\begin{array}{l}\text { Project } \\
\text { stage }\end{array}$ & $\begin{array}{c}\text { Project } \\
\text { activities }\end{array}$ & $\begin{array}{c}\text { Co-creation } \\
\text { activities }\end{array}$ & Resources & Capabilities \\
\hline \multirow{4}{*}{ Planning } & $\begin{array}{l}\text { Identifying } \\
\text { the client } \\
\text { problem }\end{array}$ & $\begin{array}{l}\text { Co-identification } \\
\text { of the client's } \\
\text { problem }\end{array}$ & $\begin{array}{l}\text { Expert knowledge } \\
\text { Diagnosing skills } \\
\text { Communication skills } \\
\text { Finances } \\
\text { Human resources } \\
\text { Technology }\end{array}$ & $\begin{array}{l}\text { Negotiation capabilities } \\
\text { Relational capabilities } \\
\text { Analytical capabilities } \\
\text { Management capabilities }\end{array}$ \\
\hline & $\begin{array}{l}\text { Generating } \\
\text { of ideas for } \\
\text { problem } \\
\text { solution }\end{array}$ & & $\begin{array}{l}\text { Experience } \\
\text { Communication skills } \\
\text { Finances } \\
\text { Human resources } \\
\text { Technology }\end{array}$ & $\begin{array}{l}\text { Negotiation capabilities } \\
\text { Relational capabilities } \\
\text { Creativity } \\
\text { Management capabilities }\end{array}$ \\
\hline & $\begin{array}{l}\text { Evaluating } \\
\text { the ideas }\end{array}$ & $\begin{array}{l}\text { Co-evaluation } \\
\text { of ideas }\end{array}$ & $\begin{array}{l}\text { Expert knowledge } \\
\text { Communication skills } \\
\text { Trust } \\
\text { Finances } \\
\text { Human resources } \\
\text { Technology }\end{array}$ & $\begin{array}{l}\text { Negotiation capabilities } \\
\text { Relational capabilities } \\
\text { Management capabilities }\end{array}$ \\
\hline & $\begin{array}{l}\text { Preparing } \\
\text { the proposal }\end{array}$ & & $\begin{array}{l}\text { Expert knowledge } \\
\text { Communication skills } \\
\text { Finances } \\
\text { Human resources } \\
\text { Experience } \\
\text { Technology }\end{array}$ & $\begin{array}{l}\text { Organizational flexibility } \\
\text { Learning agility } \\
\text { Planning capabilities } \\
\text { Analytical capabilities } \\
\text { Innovative capabilities } \\
\text { Management capabilities }\end{array}$ \\
\hline
\end{tabular}




\begin{tabular}{|c|c|c|c|c|}
\hline \multirow{5}{*}{ Build-up } & $\begin{array}{l}\text { Analysis of the } \\
\text { client business } \\
\text { environment }\end{array}$ & $\begin{array}{l}\text { Co-analysis } \\
\text { of the } \\
\text { environment }\end{array}$ & $\begin{array}{l}\text { Expert knowledge } \\
\text { Finances } \\
\text { Human resources } \\
\text { Technology }\end{array}$ & $\begin{array}{l}\text { Analytical capabilities } \\
\text { Innovative capabilities } \\
\text { Management capabilities }\end{array}$ \\
\hline & $\begin{array}{l}\text { Defining the } \\
\text { client's } \\
\text { requirements }\end{array}$ & $\begin{array}{l}\text { Co-defining } \\
\text { of client's } \\
\text { requirements }\end{array}$ & $\begin{array}{l}\text { Expert knowledge } \\
\text { Communication skills } \\
\text { Finances } \\
\text { Human resources } \\
\text { Technology }\end{array}$ & $\begin{array}{l}\text { Negotiation capabilities } \\
\text { Analytical capabilities } \\
\text { Management capabilities }\end{array}$ \\
\hline & $\begin{array}{l}\text { Translating } \\
\text { client } \\
\text { requirements } \\
\text { into water } \\
\text { system design } \\
\text { requirements }\end{array}$ & & $\begin{array}{l}\text { Expert knowledge } \\
\text { Communication skills } \\
\text { Finances } \\
\text { Human resources } \\
\text { Technology }\end{array}$ & $\begin{array}{l}\text { Negotiation capabilities } \\
\text { Analytical capabilities } \\
\text { Management capabilities }\end{array}$ \\
\hline & $\begin{array}{l}\text { Design } \\
\text { of water } \\
\text { system }\end{array}$ & Co-design & $\begin{array}{l}\text { Human resources } \\
\text { Expert knowledge } \\
\text { Communication skills } \\
\text { Trust } \\
\text { Finances } \\
\text { Technology }\end{array}$ & $\begin{array}{l}\text { Creativity } \\
\text { Innovative capabilities } \\
\text { Analytical capabilities } \\
\text { Management capabilities }\end{array}$ \\
\hline & $\begin{array}{l}\text { Ordering } \\
\text { of components }\end{array}$ & & $\begin{array}{l}\text { Finances } \\
\text { Human resources } \\
\text { Technology }\end{array}$ & $\begin{array}{l}\text { Planning capabilities } \\
\text { Management capabilities }\end{array}$ \\
\hline \multirow{4}{*}{$\begin{array}{l}\text { Implemen- } \\
\text { tation }\end{array}$} & Production & Co-production & $\begin{array}{l}\text { Human resources } \\
\text { Technological } \\
\text { equipment } \\
\text { Expert knowledge } \\
\text { Experience } \\
\text { Finances } \\
\text { Technology }\end{array}$ & $\begin{array}{l}\text { Planning capabilities } \\
\text { Innovative capabilities } \\
\text { Organizational flexibility } \\
\text { External knowledge } \\
\text { absorptive capabilities } \\
\text { Management capabilities }\end{array}$ \\
\hline & $\begin{array}{l}\text { Delivery } \\
\text { of the } \\
\text { equipment } \\
\text { to client }\end{array}$ & & $\begin{array}{l}\text { Human resources } \\
\text { Technological } \\
\text { equipment } \\
\text { Finances } \\
\text { Technology }\end{array}$ & $\begin{array}{l}\text { Organizational flexibility } \\
\text { Planning capabilities } \\
\text { Management capabilities }\end{array}$ \\
\hline & $\begin{array}{l}\text { Testing and } \\
\text { adaptation }\end{array}$ & $\begin{array}{l}\text { Co-testing and } \\
\text { co-adaptation }\end{array}$ & $\begin{array}{l}\text { Technological } \\
\text { equipment } \\
\text { Expert knowledge } \\
\text { Confidence } \\
\text { Finances } \\
\text { Human resources } \\
\text { Technology }\end{array}$ & $\begin{array}{l}\text { Relational capabilities } \\
\text { Cross-cultural capabilities } \\
\text { External knowledge } \\
\text { absorptive capabilities } \\
\text { Management capabilities }\end{array}$ \\
\hline & $\begin{array}{l}\text { Water system } \\
\text { launch }\end{array}$ & & $\begin{array}{l}\text { Technological } \\
\text { equipment } \\
\text { Expert knowledge } \\
\text { Finances } \\
\text { Human resources } \\
\text { Technology }\end{array}$ & $\begin{array}{l}\text { Relational capabilities } \\
\text { Management capabilities }\end{array}$ \\
\hline
\end{tabular}




\begin{tabular}{|c|c|c|c|c|}
\hline Ioseout & $\begin{array}{l}\text { Activities after } \\
\text { the launch }\end{array}$ & $\begin{array}{l}\text { Co-activities } \\
\text { after the launch } \\
\text { (e.g. mutual } \\
\text { information } \\
\text { exchange, } \\
\text { co-learning) }\end{array}$ & $\begin{array}{l}\text { Communication skills } \\
\text { Trust } \\
\text { Finances } \\
\text { Human resources } \\
\text { Technology }\end{array}$ & $\begin{array}{l}\text { Relational capabilities } \\
\text { Management capabilities }\end{array}$ \\
\hline
\end{tabular}

Source: own elaboration.

The interviewed project managers frequently mentioned operant (intangible) resources such as expert knowledge, diagnostic skills, experience, communication skills, technology, and trust. They much less frequently spoke about tangible (operand) resources such as finances, technology, or technological equipment. The financial resources and technology were highlighted as vital for engineering projects: they were identified as necessary for every project activity and implementation. needed for everyone's project activity. According to the interviewees, dependence on these resources is a particular feature of engineering projects. Human resources and expert knowledge were named as other obligatory engineering project resources. Project managers emphasized that the number of project workers influences the quality and timeliness of the project.

Table 8 shows the capabilities employed by engineering service innovation project workers at the different stages of the project. In the planning, development, and implementation stages of the project, managers mentioned 15 capabilities compared to just two in the closeout stage. Many capabilities are necessary for different co-creation activities. Project management capabilities were named as the most important capabilities: they are significant for all project activities. A growing number of engineering service innovation projects become increasingly complex, so effective project management capabilities are critical. In the context of the growing complexity and sophistication of projects, what is increasingly often required are analytical capabilities (in the build-up stage), negotiation capabilities (in the planning and build-up stages), and innovative capabilities (in the build-up and implementation stages). The interviewees noted that innovative capabilities are the keystone to innovate and help them to continuously transform knowledge and ideas into new products and services, facilitated in applying appropriate technologies to develop new engineering solutions in order to meet market needs and eliminate competitive threats.

To successfully conduct projects, the managers should be able to build and develop relationships with project teams and clients. Thus, relational capabilities are common at different project stages. Project teams establish and maintain diverse relations with many different actors like clients, partners, and suppliers. In the interviewed managers' opinion, all project workers and project managers should possess perfect relational 
capabilities. Moreover, the relational capabilities enable the company to secure access to external knowledge and competencies needed for innovation. The relational capabilities also help project managers to motivate, inspire, and coach project teams.

Despite the fact that four out of the five studied projects are international, cross-cultural capabilities were mentioned only once. These capabilities play an important role in face-to-face relationships when a water system is co-tested and co-adapted in a business client company.

In summary, engineering service innovation projects are realized by company-client co-creation activities that employ a plethora of resources and capabilities.

\section{Discussion}

Scholars indicate that we should devote more attention to explaining what resources and capabilities contribute to a company's service innovation and how. According to many, companies that develop resource-oriented practices enrich service innovation capabilities and win over competition more easily. Theoretical research on company-level resources and capabilities that influence service innovation is quite numerous, but empirical research offers merely scarce and scattered results so far. In order to bridge this gap, we took a step toward providing empirical findings from an international engineering company's practice that employs resources and capabilities for value co-creation in the development of innovative engineering solutions.

As mentioned above, the aim of this study was to reveal what service provider's resources and capabilities are employed to create engineering service innovation through value co-creation and how these resources and capabilities vary in different project stages of engineering service innovation. In order to reach this aim, I selected the qualitative methodology, which enabled me to better understand the complex reality and meaning of actions in the engineering service innovation context. The results of senior managers' focus group discussion showed that the company's distinctive features found the success of its engineering service innovation projects as leading in water treatment technologies and first choice for clients, partners, and suppliers. For that purpose, the company constantly invests in the research and development of advanced technologies, expanding its production base and investing in employee development. Moreover, the senior managers indicated the scope of resources and capabilities valid to maintain these particular features of the company. Most of these capabilities are operants, which means they determine service innovativeness and influence the 
company's competitive advantage, i.e. the capabilities are reputation, trust, expert knowledge, experience, organizational flexibility, learning agility, and knowledge absorption. These findings show similarities with the previous research by e.g. García-Sánchez et al. (2018) or Stelmaszczyk (2020) who state that absorptive capacity impacts organizational innovation and organizational performance. Moreover, Beraha et al. (2018) indicate that the need for company flexibility reactions increases with environmental change and uncertainty.

Despite the leading role of operant resources, the finances and technological equipment (operand resources) were named as the basis for engineering innovation. These findings agree with the previous research. Technology as a critical resource in creating value and service innovation is mentioned by Akaka and Vargo (2014), Rusanen et al. (2014), and Vargo et al. (2015). Furthermore, Kim (2020) proved the significant relationship between financial resources and innovation in huge and complex engineering projects.

While the discussion of the senior managers' focus group provided a general view of the engineering company's operations, the project managers' interviews gave me insight into engineering project practices. In this research, the creating of engineering service innovation is considered as a project consisting of four stages - planning, build-up, implementation, and closeout - with numerous co-creation activities in each of them (Duffy, 2008). This result shows similarities with e.g. Marinkovic et al. (2017) who analyzed innovative ICT projects as the creation of innovation by the development of the client's problem solution.

Every stage in an engineering innovation project consists of different activities. Despite the differences in duration of the analyzed engineering service innovation projects, we identified 14 similar activities. Some of them are performed by the service provider, other require clients' input, namely the co-identification of problems, the co-evaluation of ideas, the co-defining of requirements, the co-analysis of environment, co-design, co-testing, co-adoption, co-production, and post-launch co-activities.

From this viewpoint, my study shows most similarities with the work by Marcos-Cuevas et al. (2016). Active client in engineering service innovation projects agrees with previous research, which has found that the role of the client has significantly changed in recent years from passive recipient to value co-creator (Pezzotta et al., 2017). Value co-creation refers to the value created by the joint activities of the parties (Balaji and Roy, 2017). Grönroos (2011) mentions three value co-creation spheres: the provider's, joint, and the client's. My study confirms that value co-creation in engineering service innovation projects occurs in the joint sphere, namely during the interaction between 
the engineering company and the client - and in the provider sphere. Value co-creation between the company and the client is revealed in eight project activities: (1) problem identification, (2) ideas evaluation, (3) the analysis of the client business environment, (4) requirements definition, (5) water system design, (6) production, (7) testing and adaption, and (8) post-launch activities. The other six project activities are realized without client resources integration. I mean here (9) generating ideas for problem-solving, (10) proposal preparation, (11) translating client requirements into water system requirements, (12) components ordering, (13) delivering the equipment to the client, and (14) water system launch.

Usually, engineering projects are complex and take long, so the company often faces the challenge of properly optimizing the distribution of resources among different projects. Resources are the core elements that support the value co-creation process (Plouffe et al., 2019), including service innovation. In this regard, it is useful to know what resources will be needed at every stage of implementing projects. Our research reveals that in project planning the company identifies clients' business problems, generates ideas to solve the problems, evaluates these ideas, and prepares a proposal. Two value co-creation activities with the client - co-identification of problem and co-evaluation of ideas - are specified as common to all projects' planning stages. To succeed in an engineering service innovation project planning, the company requires expert knowledge, diagnosing, and communication skills. The crucial role of expert knowledge in water-related projects is confirmed by van Ast et al. (2017). Zuo et al. (2018) argue that effective communication in project management helps to achieve team cohesiveness, mutual understanding, and a sense of ownership in the project. The identified resources of the project planning stage in the engineering service innovation are augmented by negotiation and relation-building capabilities.

The projects' build-up stage includes five activities: (1) business environment analysis, (2) requirements definition, (3) translating these client's requirements into water system design specifications, (4) water system design, and (5) ordering the components necessary for the water system. During this project stage, the company engages the clients to co-create the analysis of their business environment, co-define the requirements of the water system, and co-design the water system. As well as planning, the build-up stage demands expert knowledge and communication skills. Nevertheless, the more important resources are finances, human resources, and trust. The role of trust is accentuated by Bond-Barnard et al. (2018). Their research findings show that the level of trust in a project stimulates the degree of collaboration. Among significant capabilities at this stage of engineering projects, the following were outlined: analytical, innovative, negotiation, creative, and planning capabilities. Analytical, innovative, and planning capabilities 
have similarities with the work of Mainga (2017) who studied project management competencies that encompass project team's capabilities to assess complex and fluid situations and to better estimate project costs, schedule, and project risks. As Mainga (2017) affirms, these capabilities enhance project efficiency in the case of scarce financial resources. Biedenbach and Müller (2012) stress that innovative capabilities in early project phases have a significant positive impact on long-term project success.

The subsequent project stage - implementation - includes the equipment production process, the delivery of the equipment to the client, the testing and adoption of the equipment, and the launch of the entire water system activities. As value co-creators, clients take part in the production process and testing, but also in the adaptation of the water system activities. While implementing this project's stage, the company's production capacity and human resources play the main role. This determines whether the project will be implemented in a timely and high-quality manner. In addition to production capacity and human resources, intangible resources such as expert knowledge, experience, and trust are inseparable from successful project implementation. The issue of the mentioned resources, which will be employed appropriately during project implementation, rely on the company's capabilities. In relation to planning, innovative, and relational capabilities mentioned at earlier stages of the project, the implementation stage is particularly due to request for the external knowledge absorptive, organizational flexibility and cross-cultural capabilities.

Many of these findings are consistent with previous research. Flor et al. (2018) state that absorbing external knowledge exerts a direct influence on radical innovation in high-tech companies. Searching widely and deeply across external sources can provide ideas and resources that help firms gain and exploit innovative opportunities. An absorptive capacity allows firms to recognize the value of new, external information, assimilate it, and apply it to commercial ends (Kazadi et al., 2016). Forés's and Camison's (2016) industrial firms' research findings confirm that absorptive capability acts on the development of new products, processes, technologies, and management methods. My study revealed that absorbing external knowledge is needed during the project implementation phase. This result is not aligned with Eslami and Lakemond (2016) study's findings. Their study shows that capturing customers' knowledge in terms of requirements and specifications is important in the project ideation phase. Saeed et al. (2020) reveal the positive influence of organizational flexibility on project portfolio management. It is important for project-based organizations, which manage different projects that require flexibility. As engineering projects are increasingly cross-cultural, the diversity of participants can enhance the differences in perceptions and understanding of the meaning of the variety of signals - e.g. the drawings and messages in 
construction projects (Fellows and Liu, 2016) - so the company's cross-cultural capabilities are gaining in importance. Johnsen and Ford (2006) stress that the capability to manage cross-cultural relationships and to establish a position in new networks is critical, especially when a smaller company is entered into a relationship with a larger client, which is the case in my study.

The last project stage at the scrutinized company is closeout, which encompasses the activities performed after the entire launch of the water system in the client's business. The company makes efforts to ensure strong relationships with clients. In turn, clients are also interested in the company's support during the functioning of the water system. Among the co-creating activities, there are two: (1) mutual information exchange and (2) co-learning. These activities are based on good communication skills, trust, and relation capabilities. As my research shows, the latter are desirable at all stages of the engineering project. This finding shows a connection to the results of Ngugi et al. (2010) study. Their findings suggest that the identified set of relational capabilities may be employed by small and medium-sized suppliers to enable them to support innovation and the implementation of initiatives so as to create value. In turn, Kusa (2020) states that the access to external resources, their utilization, and sharing of their resources are the most important aspects of relational capabilities.

\section{Concluding Remarks}

In this article, (1) we outlined the eighteen activities that cover four stages of engineering service innovation projects, (2) identified the range of activities that are performed by the engineering company autonomously, (3) revealed the scope of activities required the contribution of clients, i.e. the activities as value co-creation between the company and client, (4) discovered how the resources and capabilities vary in different engineering service innovation project stages and activities, and (5) determined what resources and capabilities are vitally important for value co-creation in engineering service innovation project. However, we are sure that the area of resources and capabilities in value co-creation during the engineering service innovation project is in its infancy and many aspects are insufficiently understood and need further research.

\section{Theoretical and Managerial Implications}

The study makes theoretical contributions related to the knowledge of value co-creation, resources, and capabilities in a specific context - that of engineering service innovation projects. First, the study discloses a set of activities for value co-creation 
performed by the engineering company and clients at different stages of engineering service innovation projects. Second, the study reveals what resources and capabilities are employed in engineering service innovation projects and how they vary in the project stage by stage. Both these contributions could be treated as a novelty of the study because in previous studies researchers focused on one type of resource or capability used at a particular stage of the project (i.e. implementation).

The success of engineering services innovation projects plays a significant role in the development of businesses. Thus, the study provides valuable information for executives of engineering companies. Value co-creation with clients has produced widely publicized successes at some companies. Nevertheless, practitioners face the challenges to building a co-creative company and the model of value co-creation with clients. The study shows the need for close relationships between the company's management team and project members. This research helps to make decisions as to how the company will design, implement, and manage the engineering services innovation projects based on co-creation with clients. Engineering projects vary by complexity, risk, duration, and used technologies. Due to these features, the resources needed for project implementation should be carefully planned, especially human resources and finances. The study clearly shows that engineering service companies need to concentrate on the development of capabilities of project managers and project team members. This applies also to the ability to understand, initiate, and perform value co-creation through cooperation with clients.

\section{Limitations and Future Research}

The study has certain limitations that could be considered veins of future research. The study covers one engineering service company that offers water systems equipment design, manufacturing, installation, start-up, adjustment, technical support, and maintenance. Thus, more and different engineering companies could be involved in future research, hence creating new knowledge concerns employed regarding resources and capabilities, along with diversity co-creation activities. The above study was performed based on the service supplier perspective. Despite the fact that the service company is the more active actor in value co-creation, it could be useful to also involve the clients and other stakeholders in the research. 


\section{References}

Aarikka-Stenroos, L. and Jaakkola, E. (2012). Value co-creation in knowledge intensive business services: A dyadic perspective on the joint problem solving process. Industrial Marketing Management, 41(1), 15-26. http://dx.doi.org/10.1016/j.indmarman.2011.11.008.

Agrawal, A.K. and Rahman, Z. (2015). Roles and resource contributions of customers in value co-creation. International Strategic Management Review, 3(1-2), 144-160.

https://doi.org/10.1016/j.ism.2015.03.001.

Akaka, M.A. and Vargo, S.L. (2014). Technology as an operant resource in service (eco) systems. Information Systems and e-Business Management, 12(3), 367-384. http://dx.doi.org/10.1007/s10257-013-0220-5.

Allen, S., Bailetti, T. and Tanev, S. (2009). Components of Co-creation. Open Source Business Resource (November 2009). Obtained from: http://timreview.ca/article/301 (access: 24.06.2018).

Anandarajan, M., Hill, C. and Nolan, T. (2018). Practical Text Analytics: Maximizing the Value of Text Data. Cham: Springer Nature Switerland. https://doi.org/10.1007/978-3-319-95663-3_3.

Antwi, S.K., and Hamza, K. (2015). Qualitative and quantitative research paradigms in business research: A philosophical reflection. European Journal of Business and Management, 7(3), 217-225.

Arnould, E.J. (2008). Service-dominant logic and resource theory. Journal of the Academy of Marketing Science, 36(1). http://dx.doi.org/10.1007/s11747-007-0072-y.

Baark, E. (2001). Routines and innovation in engineering consultancy services. In: Nelson and Winter Conference, Aalborg, Denmark. Obtained from: http://hdl.handle.net/1783.1/3519.

Balaji, M.S. and Roy, S.K. (2017). Value co-creation with Internet of things technology in the retail industry. Journal of Marketing Management, 33(1-2), 7-31. http://dx.doi.org/10.1080/0267257X.2016.1217914.

Barney, J. (1991). Firm resources and sustained competitive advantage. Journal of Management, 17(1), 99-120. https://doi.org/10.1177/014920639101700108.

Barney, J. (2002). Gaining and sustaining competitive advantage. $2^{\text {nd }}$ ed. Upper Saddle River, NJ: Prentice Hall.

Baxter, P. and Jack, S. (2008). Qualitative Case Study Methodology: Study Design and Implementation for Novice Researchers. The Qualitative Report, 13(4), 544-556.

https://nsuworks.nova.edu/tqr/vol13/iss4/2.

Bello, D.C., Radulovich, L.P., Javalgi, R.R.G., Scherer, R.F. and Taylor, J. (2016). Performance of professional service firms from emerging markets: Role of innovative services and firm capabilities. Journal of World Business, 51(3), 413-424. http://dx.doi.org/10.1016/j.jwb.2015.11.004.

Benazzouz, N.M. (2019). Entrepreneurial orientation and innovation intensity: A synthetic literature review. International Entrepreneurship Review, 5, 23-36. https://doi.org/10.15678/IER.2019.0502.02.

Beraha, A., Bingol, D., Ozkan-Canbolat, E. and Szczygiel, N. (2018). The effect of strategic flexibility configurations on product innovation. European Journal of Management and Business Economics, 27(2), 129-140. http://dx.doi.org/10.1108/EJMBE-02-2018-0028.

Biedenbach, T. and Müller, R. (2012). Absorptive, innovative and adaptive capabilities and their impact on project and project portfolio performance. International Journal of Project Management, 30(5), 621-635. https://doi.org/10.1016/j.ijproman.2012.01.016.

Bonamigo, A., Dettmann, B., Frech, C.G., and Werner, S.M. (2020). Facilitators and inhibitors of value co-creation in the industrial services environment. Journal of Service Theory and Practice, 30(6), 609-642. https://doi.org/10.1108/JSTP-03-2020-0061. 
Bond-Barnard, T.J., Fletcher, L., and Steyn, H. (2018). Linking trust and collaboration in project teams to project management success. International Journal of Managing Projects in Business, 11(2), 432-457. https://doi.org/10.1108/IJMPB-06-2017-0068.

Campbell, N., O'Driscoll, A. and Saren, M. (2013). Reconceptualizing resources: a critique of service-dominant logic. Journal of Macromarketing, 33(4), 306-321. https://doi.org/10.1177/0276146713497755.

Carroll, N. and Helfert, M. (2015). Service capabilities within open innovation: Revisiting the applicability of capability maturity models. Journal of Enterprise Information Management, 28(2), 275-303. http://dx.doi.org/10.1108/JEIM-10-2013-0078.

Chen, K.H., Wang, C.H., Huang, S.Z. and Shen, G.C. (2016). Service innovation and new product performance: The influence of market-linking capabilities and market turbulence. International Journal of Production Economics, 172, 54-64. http://dx.doi.org/10.1016/j.ijpe.2015.11.004.

Christensen, C.M. (2013). The innovator's dilemma: when new technologies cause great firms to fail. Harvard Business Review Press.

Das, T.K., and Kumar, R. (2010). Interpartner sensemaking in strategic alliances. Management Decision, 48(1), 17-36. http://dx.doi.org/10.1108/00251741011014436.

Das, T.K. and Teng, B.S. (2000). A resource-based theory of strategic alliances. Journal of Management, 26(1), 31-61. https://doi.org/10.1016/S0149-2063(99)00037-9.

DeFillippi, R., and Roser, T. (2014). Aligning the co-creation project portfolio with company strategy. Strategy \& Leadership, 42(1), 30-36. https://doi.org/10.1108/SL-10-2013-0075.

Duffy, M.G. (2008). Managing projects: expert solutions to everyday challenges. Boston: Harvard Business School Publishing.

Edvardsson, B. and Tronvoll, B. (2013). A new conceptualization of service innovation grounded in S-D logic and service systems. International Journal of Quality \& Service Sciences, 5(1), 19-31. http://dx.doi.org/10.1108/17566691311316220.

Edvardsson, B., Meiren, T., Schäfer, A., and Witell, L. (2013). Having a strategy for new service development-does it really matter? Journal of Service Management, 24(1), 25-44. http://dx.doi. org/10.1108/09564231311304170.

Eslami, M.H. and Lakemond, N. (2016). Knowledge integration with customers in collaborative product development projects. Journal of Business \& Industrial Marketing, 31(7), 889-900. http://dx.doi.org/10.1108/JBIM-05-2014-0099.

Fellows, R., and Liu, A. (2016). Sensemaking in the cross-cultural contexts of projects. International Journal of Project Management, 34(2), 246-257. http://dx.doi.org/10.1016/j.ijproman.2015.03.010.

Fitzsimmons, J.A., and Fitzsimmons, M.J. (2006). Service Management: Operations, Strategy, and Information Technology. $4^{\text {th }}$ ed. New York: McGraw-Hill.

Flor, M.L., Cooper, S.Y. and Oltra, M.J. (2018). External knowledge search, absorptive capacity and radical innovation in high-technology firms. European Management Journal, 36(2), 183-194. http://dx.doi.org/10.1016/j.emj.2017.08.003.

Forés, B. and Camisón, C. (2016). Does incremental and radical innovation performance depend on different types of knowledge accumulation capabilities and organizational size? Journal of Business Research, 69(2), 831-848. http://dx.doi.org/10.1016/j.jbusres.2015.07.006.

Froehle, C.M., and Roth, A.V. (2007). A resource-process framework of new service development. Production and Operations Management, 16(2), 169-188. https://doi.org/10.1111/j.1937-5956.2007.tb00174.x.

Frow, P., Nenonen, S., Payne, A. and Storbacka, K. (2015). Managing Co-creation Design: A Strategic Approach to Innovation. British Journal of Management, 26(3), 463-483.

http://dx.doi.org/10.1111/1467-8551.12087. 
Galvagno, M. and Dalli, D. (2014). Theory of value co-creation: a systematic literature review. Managing Service Quality, 24(6), 643-683. https://doi.org/10.1108/MSQ-09-2013-0187.

García-Sánchez, E., García-Morales, V.J., and Martín-Rojas, R. (2018). Influence of technological assets on organizational performance through absorptive capacity, organizational innovation and internal labour flexibility. Sustainability, 10(3), 770-295. http://dx.doi.org/10.3390/su10030770.

Gemser, G. and Perks, H. (2015). Co-Creation with Customers: An Evolving Innovation Research Field. Journal of Product Innovation Management, 32(5), 660-665. http://dx.doi.org/10.1111/jpim.12279.

Giannopoulou, E., Gryszkiewicz, L. and Barlatier, P.-J. (2011). A conceptual model for the development of service innovation capabilities in research and technology organizations. International Journal of Knowledge Management Studies, 4(4), 319-335. https://doi.org/10.1504/IJKMS.2011.048441.

Gibbert, M., Ruigrok, W. and Wicki, B. (2008). What passes as a rigorous case study? Strategic Management Journal, 29(13), 1465-1474. http://dx.doi.org/10.1002/smj.722.

Grafmüller, L.K. (2020). Co-creation of High-tech Products in the B2B Domain. Wiesbaden: Springer Gabler.

Grant, R.M. (1991). The resource-based theory of competitive advantage: Implications for strategy formulation. California Management Review, 33(3), 114-135. http://dx.doi.org/10.2307/41166664.

Green, J. and Thorogood, N. (2018). Qualitative methods for health research. London: Sage.

Grönroos, C. (2011). Value co-creation in service logic: A critical analysis. Marketing Theory, 11(3), 279-301. http://dx.doi.org/10.1177/1470593111408177.

Gryszkiewicz, L., Giannopoulou, E. and Barlatier, P.J. (2013). Service innovation capabilities: what are they? International Journal of Services, Economics and Management, 22, 5(1-2), 125-153. http://dx.doi.org/10.1504/IJSEM.2013.051857.

Gummesson, E., Mele, C., Polese, F., Mele, C., Spena, T.R., and Colurcio, M. (2010). Co-creating value innovation through resource integration. International Journal of Quality and Service Sciences, 2(1), 60-78. https://doi.org/10.1108/17566691011026603.

Helkkula, A., Kowalkowski, C. and Tronvoll, B. (2018). Archetypes of service innovation: implications for value cocreation. Journal of Service Research, 21(3), 284-301. https://doi.org/10.1177/1094670517746776.

Henrie, M.E. (2014). Cultural Influences in Engineering Projects. New York: Momentum Press.

Hervas-Oliver, J.L. and Sempere-Ripoll, F. (2015). Disentangling the influence of technological process and product innovations. Journal of Business Research, 68(1), 109-118.

https://doi.org/10.1016/j.jbusres.2014.04.010.

Hogan, S.J., Soutar, G.N., McColl-Kennedy, J.R. and Sweeney, J.C. (2011). Reconceptualizing professional service firm innovation capability: Scale development. Industrial Marketing Management, 40(8), 1264-1273. http://dx.doi.org/10.1016/j.indmarman.2011.10.002.

Hsieh, H.F. and Shannon, S.E. (2005). Three approaches to qualitative content analysis. Qualitative Health Research, 15(9), 1277-1288. http://dx.doi.org/10.1177/1049732305276687.

Hsieh, J.K. and Hsieh, Y.C. (2015). Dialogic co-creation and service innovation performance in high-tech companies. Journal of Business Research, 68(11), 2266-2271. https://doi.org/10.1016/j.jbusres.2015.06.009.

Hunt, S.D. (2000). A General Theory of Competition: Resources, Competences, Productivity, Economic Growth. Thousand Oaks, Ca: Sage Publications. https://doi.org/10.4135/9781452220321.

Islam, M.A., Agarwal, N.K. and Ikeda, M. (2015). Conceptualizing value co-creation for service innovation in academic libraries. Business Information Review, 32(1), 45-52.

http://dx.doi.org/10.1177/0266382115573155. 
Janteng, J. and Tan, C.L. (2017). Effects of Value Co-Creation on Innovation Capability: Knowledge Sharing as a Moderator. In: E. Tsui and B. Cheung (eds.), ICICKM 2017 14th International Conference on Intellectual Capital Knowledge Management \& Organisational Learning: ICICKM 2017 (pp. 116-121). Reading: Academic Conferences and Publishing International Limited.

Johnsen, R.E. and Ford, D. (2006). Interaction capability development of smaller suppliers in relationships with larger customers. Industrial Marketing Management, 35(8), 1002-1015. https://doi.org/10.1016/j.indmarman.2006.05.005.

Jouny-Rivier, E., Reynoso, J. and Edvardsson, B. (2017). Determinants of services co-creation with business customers. Journal of Services Marketing, 31(2), 85-103. https://doi.org/10.1108/JSM-01-2016-0001.

Kantola, J. and Karwowski, W. (eds.) (2016). Knowledge service engineering handbook. Boca Raton: CRC Press. Obtained from: https://doi.org/10.1201/b12043.

Kaszowska-Mojsa, J. (2020). Innovation strategies of manufacturing companies during expansions and slowdowns. Entrepreneurial Business and Economics Review, 8(4), 47-66. https://doi.org/10.15678/EBER.2020.080403.

Kazadi, K., Lievens, A. and Mahr, D. (2016). Stakeholder co-creation during the innovation process: Identifying capabilities for knowledge creation among multiple stakeholders. Journal of Business Research, 69(2), 525-540. http://dx.doi.org/10.1016/j.jbusres.2015.05.009.

Kim, S.M. (2020). Payment Methods and Finance for International Trade. Singapore: Springer.

Kim, M., Song, J. and Triche, J. (2015). Toward an integrated framework for innovation in service: A resource-based view and dynamic capabilities approach. Information Systems Frontiers, 17(3), 533-546. http://dx.doi.org/10.1007/s10796-014-9505-6.

Koryak, O., Mole, K.F., Lockett, A., Hayton, J.C., Ucbasaran, D. and Hodgkinson, G.P. (2015). Entrepreneurial leadership, capabilities and firm growth. International Small Business Journal, 33(1), 89-105. https://doi.org/10.1177/0266242614558315.

Kusa, R. (2020). Linking relational capabilities and entrepreneurial orientation of an organization. International Entrepreneurship Review, 6(3), 49-60. https://doLorg/10.15678/IER.2020.0603.04.

Legum, B.M., Stiles, A.R. and Vondran, J.L. (2019). Engineering Innovation. From idea to market through concepts and case studies. De Gruyter.

Lichtenstein, B.M. and Brush, C.G. (2001). How do "resource bundles" develop and change in new ventures? A dynamic model and longitudinal exploration. Entrepreneurship Theory and Practice, 25(3), 37-58. https://doi.org/10.1177/104225870102500303.

Lindgreen, A., Hingley, M.K., Grant, D.B. and Morgan, R.E. (2012). Value in business and industrial marketing: Past, present, and future. Industrial Marketing Management, 41(1), 207-214. http://dx.doi.org/10.1016/j.indmarman.2011.11.025.

Löfsten, H. (2016). Organisational capabilities and the long-term survival of new technology-based firms. European Business Review, 28(3), 312-332. http://dx.doi.org/10.1108/EBR-04-2015-0041.

Løwendahl, B.R. (2005). Strategic Management of Professional Service Firms. $3^{\text {rd }}$ ed. Koge: Copenhagen Business Scholl Press.

Mahr, D., Lievens, A. and Blazevic, V. (2014). The value of customer cocreated knowledge during the innovation process. Journal of Product Innovation Management, 31(3), 599-615. http://dx.doi.org/10.1111/jpim.12116.

Mainga, W. (2017). Examining project learning, project management competencies, and project efficiency in project-based firms (PBFs). International Journal of Managing Projects in Business, 10(3), 454-504. https://doi.org/10.1108/IJMPB-04-2016-0035.

Malhotra, N. and Morris, T. (2009). Heterogeneity in professional service firms. Journal of Management Studies, 46(6), 895-922. http://dx.doi.org/10.1111/j.1467-6486.2009.00826.x. 
Marcos-Cuevas, J., Nätti, S., Palo, T., and Baumann, J. (2016). Value co-creation practices and capabilities: Sustained purposeful engagement across B2B systems. Industrial Marketing Management, 56, 97-107. http://dx.doi.org/10.1016/j.indmarman.2016.03.012.

Marinkovic, S., Jovanovic, M. and Petkovic, J. (2017). Co-creation as innovation model in ICT based services. In: P. Ketikidis and A. Solomon (eds.), Conference proceedings University-Industry Links: Coproducing Knowledge. Innovation \& Growth.

Michel, S., Brown, S.W. and Gallan, A.S. (2008). An expanded and strategic view of discontinuous innovations: deploying a service-dominant logic. Journal of the Academy of Marketing Science, 36(1), 54-66. https://doi.org/10.1007/s11747-007-0066-9.

Miller, R. and Lessard, D. (2001). Understanding and managing risks in large engineering projects. International Journal of Project Management, 19(8), 437-443. http://dx.doi.org/10.1016/S0263-7863(01)00045-X.

Miller, R. and Lessard, D.R. (2001a). The Strategic Management of Large Engineering Projects: Shaping Institutions, Risks, and Governance. MIT Press. http://dx.doi.org/10.7551/mitpress/6478.001.0001.

Ngugi, I.K., Johnsen, R.E. and Erdélyi, P. (2010). Relational capabilities for value co-creation and innovation in SMEs. Journal of Small Business and Enterprise Development, 17(2), 260-278. http://dx.doi.org/10.1108/14626001011041256.

Nicholas, J.M. and Steyn, H. (2017). Project management for engineering, business and technology. Fourth edition. New York: Routledge.

O’Connor, G.C. (2008). Major innovation as a dynamic capability: A systems approach. Journal of Product Innovation Management, 25(4), 313-330. https://doi.org/10.1111/j.1540-5885.2008.00304.X.

Ostrom, A.L., Bitner, M.J., Brown, S.W., Burkhard, K.A., Goul, M., Smith-Daniels, V., Demirkan, H. and Rabinovich, E. (2010). Moving forward and making a difference: research priorities for the science of service. Journal of Service Research, 13(1), 4-36. https://doi.org/10.1177/1094670509357611.

Paradkar, A., Knight, J. and Hansen, P. (2015). Innovation in start-ups: Ideas filling the void or ideas devoid of resources and capabilities? Technovation, 41, 1-10. https://doi.org/10.1016/j.technovation.2015.03.004.

Paredes, M.R., Barrutia, J.M. and Echebarria, C. (2014). Resources for value co-creation in e-commerce: a review. Electronic Commerce Research, 14(2), 111-136. https://doi.org/10.1007/s10660-014-9135-6.

Pezzotta, G., Cavalieri, S. and Romero, D. (2017). Collaborative product-service systems engineering: Towards an active role of customers and stakeholders in value co-creation. In: 2017 International Conference on Engineering, Technology and Innovation (ICE/ITMC) (pp. 1247-1254). IEEE. http://dx.doi.org/10.1109/ICE.2017.8280023.

Plouffe, C. R., Nagel, D., Bonney, L., Hochstein, B. and Salas, J. (2020). The Austrian view and value co-creation process in solution-oriented firms: A seven stage,"solution prototyping” framework. Journal of Marketing Theory and Practice, 28(1), 79-97. http://dx.doi.org/10.1080/10696679.2019.1671202.

Queirós, A., Faria, D. and Almeida, F. (2017). Strengths and limitations of qualitative and quantitative research methods. European Journal of Education Studies, 3(9), 369-387. http://dx.doi.org/10.46827/ejes.v0i0.1017.

Roller, M.R. and Lavrakas, P.J. (2015). Applied qualitative research design: A total quality framework approach. New York: Guildford Publications.

Rusanen, H., Halinen, A., and Jaakkola, E. (2014). Accessing resources for service innovation-the critical role of network relationships. Journal of Service Management, 25(1), 2-29. http://dx.doi.org/10.1108/JOSM-10-2012-0219.

Saeed, M.A., Jiao, Y., Zahid, M.M., Tabassum, H. and Nauman, S. (2020). Organizational flexibility and project portfolio performance: the roles of innovation, absorptive capacity and environmental 
dynamism. International Journal of Managing Projects in Business, 14(3), 600-624.

https://doi.org/10.1108/IJMPB-02-2020-0058.

Sáenz, J., Aramburu, N. and Rivera, O. (2009). Knowledge sharing and innovation performance: A comparison between high-tech and low-tech companies. Journal of Intellectual Capital, 10(1), 22-36. https://doi.org/10.1108/14691930910922879.

Santos-Vijande, M.L., López-Sánchez, J.A. and Gonzalez-Mieres, C. (2012). Organizational learning, innovation, and performance in KIBS. Journal of Management $\&$ Organization, 18(6), 870-904. https://doi.org/10.5172/jmo.2012.18.6.870.

Siegel, N.G. (2019). Engineering Project Management. Chichester: John Wiley \& Sons. https://doi.org/10.1002/9781119525813.

Sirmon, D.G., Hitt, M.A. and Ireland, R.D. (2007). Managing firm resources in dynamic environments to create value: Looking inside the black box. Academy of Management Review, 32(1), 273-292. https://doi.org/10.5465/amr.2007.23466005.

Snyder, H., Witell, L., Gustafsson, A., Fombelle, P. and Kristensson, P. (2016). Identifying categories of service innovation: A review and synthesis of the literature. Journal of Business Research, 69(7), 2401-2408. https://doi.org/10.1016/j.jbusres.2016.01.009.

Sørensen, F. and Lapenta, F. (2017). Service innovations research methods. In: F. Lapenta and F. Sørensen (eds.), Research Methods in Service Innovation (pp. 1-18). Cheltenham: Edward Elgar Publishing. http://dx.doi.org/10.4337/9781785364860.00007.

Stake, R. (2005). Qualitative case studies. In: N.K. Denzin and Y.S. Lincoln (eds.), The Sage handbook of qualitative research ( $3^{\text {th }}$ ed., pp. 443-466). Thousands Oaks, Ca: Sage Publications.

Stelmaszczyk, M. (2020). How Absorptive Capacity and Organisational Learning Orientation Interact to Enable Innovation Capability? An Empirical Examination. Entrepreneurial Business and Economics Review, 8(1), 7-32. https://doi.org/10.15678/EBER.2020.080101.

Stošić, B. and Milutinović, R. (2017). Key Issues to Improve Innovation Project Excellence. In: B.L. Moya, M.D. Storch de Gracia and L.F. Mazadiego (eds.), Key Issues for Management of Innovative Projects, 25-44. http://dx.doi.org/10.5772/67504.

Strønen, F., Hoholm, T., Kværner, K.J. and Støme, L.N. (2017). Dynamic capabilities and innovation capabilities: The case of the 'Innovation Clinic.' Journal of Entrepreneurship, Management and Innovation, 13(1), 89-116. http://dx.doi.org/10.7341/20171314.

Sułkowski, L. and Patora-Wysocka, Z. (2020). International entrepreneurship of universities: Process-oriented and capabilities perspectives. Entrepreneurial Business and Economics Review, 8(3), 175-188. https://doi.org/10.15678/EBER.2020.080310.

Teece, D.J. (2014). A dynamic capabilities-based entrepreneurial theory of the multinational enterprise. Journal of International Business Studies, 45(1), 8-37. http://dx.doi.org/10.1057/jibs.2013.54.

Ulin, P.R., Robinson, E.T. and Tolley, E.E. (2005). Qualitative Methods in Public Health. A Field Guide for Applied Research. 1st edition. San Francisco: Jossey-Bass.

Urueña, A., Hidalgo, A. and Arenas, Á.E. (2016). Identifying capabilities in innovation projects: Evidences from eHealth. Journal of Business Research, 69(11), 4843-4848. https://doi.org/10.1016/j.jbusres.2016.04.041.

van Ast, J.A. and Gerrits, L. (2017). Public participation, experts and expert knowledge in water management in the Netherlands. Water Policy, 19(1), 115-127. https://doi.org/10.2166/wp.2016.253.

Vargo, S.L. and Lusch, R.F. (2008). Why service? Journal of the Academy of Marketing Science, 36(1), 25-38. http://dx.doi.org/10.1007/s11747-007-0068-7.

Vargo, S.L., Wieland, H. and Akaka, M.A. (2015). Innovation through institutionalization: A service ecosystems perspective. Industrial Marketing Management, 44, 63-72.

http://dx.doi.org/10.1016/j.indmarman.2014.10.008. 
Von Nordenflycht, A. (2010). What is a professional service firm? Toward a theory and taxonomy of knowledge-intensive firms. Academy of Management Review, 35(1), 155-174. http://dx.doi.org/10.5465/AMR.2010.45577926.

Yin, R.K. (2014). Case Study Research. Design and Methods. $5^{\text {th }}$ ed. Thousand Oaks: Sage.

Zuo, J., Zhao, X., Nguyen, Q.B.M., Ma, T. and Gao, S. (2018). Soft skills of construction project management professionals and project success factors. Engineering, Construction and Architectural Management, 25(3), 425-442. https://doi.org/10.1108/ECAM-01-2016-0016. 